\title{
Pengaruh Kebisingan Terhadap Tekanan Darah dan Nadi pada Pekerja Pabrik Kayu PT. Muroco Jember
}

\author{
Wahyu Ikhwan Nanda Mukhlish', Yohanes Sudarmanto ${ }^{2}$, Muhammad Hasan ${ }^{3}$ \\ ${ }^{1}$ Pendidikan Dokter, Fakultas Kedokteran, Universitas Jember \\ ${ }^{2}$ Laboratorium Kesehatan Masyarakat, Fakultas Kedokteran, Universitas Jember \\ ${ }^{3}$ Laboratorium Anatomi, Fakultas Kedokteran, Universitas Jember \\ Corresponding author: 142010101004@students.unej.ac.id
}

Info Artikel : Diterima Januari 2018 ; Disetujui Juli 2018 ; Publikasi Oktober 2018

\begin{abstract}
ABSTRAK
Latar belakang: Kebisingan merupakan bunyi yang memiliki intensitas di atas batas normal dan dapat mengganggu kesehatan pada orang yang terpapar. Paparan kebisingan terjadi dalam proses produksi pada industri pabrik kayu, sehingga pekerja menjadi pihak utama yang terdampak. Dampak yang terjadi utamanya pada sistem kardiovaskular. Penelitian ini bertujuan untuk menganalisis pengaruh kebisingan terhadap tekanan darah dan denyut nadi pada pekerja pabrik kayu PT. Muroco Jember.

Metode: Penelitian ini berjenis analitik observasional dengan desain penelitian cross sectional. Responden penelitian berjumlah 24 orang yang diambil dengan teknik total sampling. Pengukuran kebisingan menggunakan alat sound level meter. Pengumpulan data karakteristik pekerja menggunakan kuesioner. Responden penelitian diukur sebelum dan setelah bekerja, dengan menggunakan sphygmomanometer air raksa untuk tekanan darah dan penghitungan manual denyut nadi pada arteri brachialis. Analisis data menggunakan uji komparasi paired t-test pada level signifikansi 5\%.

Hasil: Intensitas kebisingan dari 4 sektor kerja menunjukkan hasil yang beragam. Intensitas kebisingan terendah pada sektor produksi A yaitu 82,9 dB(A), sedangkan tertinggi pada sektor sawmill B yaitu 98,1 dB(A). Sebagian besar responden $(66,7 \%)$ berusia 29-40 tahun dengan masa kerja responden $(62,5 \%)$ kurang dari 2 tahun. Sebanyak 91,7\% responden tidak memakai APT pada saat bekerja. Berdasarkan uji komparasi paired t-test, didapatkan pengaruh paparan kebisingan akut antara sebelum dan setelah bekerja terhadap tekanan darah sistolik ( $p=<0,001)$, diastolik $(p=0,049)$, dan denyut nadi $(p=0,020)$.

Simpulan: Terdapat peningkatan yang signifikan terhadap tekanan darah sistolik, diastolik, denyut nadi antara sebelum dan setelah bekerja dalam paparan kebisingan akut pada pekerja pabrik kayu PT. Muroco Jember. Diperlukan penelitian dengan mengendalikan variabel lain yang mengganggu untuk kesempurnaan penelitian selanjutnya.
\end{abstract}

Kata kunci: Kebisingan; tekanan darah; denyut nadi; pabrik kayu

\section{ABSTRACT}

Title: The Effect of Noise on Blood Pressure and Pulse Rate in Workers at PT. Muroco Jember Wood Factory Background: Noise is a sound that has an intensity above the normal limit and may interfere with the health of the exposed person. Exposure to noise often occurs in the production process at the wood processing factory, so that workers become the main person affected. The impact mainly occurs in cardiovascular system. This study aims to analyze the effect of noise on blood pressure and pulse rate in workers at PT. Muroco Jember wood factory.

Method: This is an observational analytic research with cross sectional design. The respondents amounted to 24 people taken with total sampling technique. The measurement of noise intensity was using sound level meter. Data collecting of worker characteristics was using questionnaires. Respondents were measured before and after work, using a mercury sphygmomanometer for blood pressure and manual palpation of pulse rate in the brachial artery. Data was analyzed with paired t-test comparative at 5\% significance level. 
Result: The noise intensity of 4 sectors of the factory showed diverse results. The lowest noise intensity is in production sector $A, 82.9 \mathrm{~dB}(A)$, while the highest is in sawmill B sector, $98.1 \mathrm{~dB}(\mathrm{~A})$. Most of the respondents (66.7\%) were 29-40 years old with respondents working period (62.5\%) were less than 2 years. As many as $91.7 \%$ of respondents did not use ear protection device while working. Based on paired t-test, there was an effect of acute exposure between before and after working on systolic blood pressure $(p<0,001)$, diastolic $(p=0.049)$, and pulse rate $(p=0.020)$

Conclusion: There was a significant increase in systolic, diastolic blood pressure, and pulse rate between before and after work in an acute noise exposure in worker at PT. Muroco Jember wood factory. Further research is required by controlling other disturbing variables for a better research.

Keywords: Noise; blood pressure; pulse rate; wood factory

\section{PENDAHULUAN}

Kebisingan (noise) berasal dari bahasa latin nausea yang artinya adalah bunyi yang tidak diinginkan. ${ }^{1,2}$ Kebisingan dapat didefinisikan sebagai bunyi dengan intensitas melebihi batas normal yang berasal dari usaha atau kegiatan dalam tingkat dan waktu tertentu, sehingga dapat menyebabkan gangguan dalam berkomunikasi, gangguan kesehatan, dan berdampak terhadap kenyamanan lingkungan. ${ }^{3,4}$

Sekitar lebih dari $70 \%$ sumber kebisingan berasal dari aktivitas industri pada pabrik. ${ }^{1}$ Implikasi dari fakta tersebut adalah para pekerja pabrik akan menjadi pihak pertama yang terkena paparan kebisingan secara intens dan memiliki risiko terdampak oleh hal tersebut. ${ }^{1,5}$ Dampak kebisingan terhadap kesehatan pekerja dibagi menjadi dampak terhadap pendengaran dan non pendengaran. Dampak terhadap pendengaran meliputi gangguan keseimbangan, gangguan pendengaran, hingga hilangnya pendengaran secara permanen. ${ }^{5}$ Dampak non pendengaran antara lain peningkatan tekanan darah, abnormalitas electrocardiography, gangguan psikologis, gangguan fisiologis tubuh, dan gangguan tingkah laku. 5,6,7,8

Penelitian Gopinath et al. (2011) menyatakan bahwa pekerja yang terpapar kebisingan dengan intensitas sangat tinggi untuk durasi kurang dari lima tahun, berisiko tiga kali lebih tinggi terkena stroke dan $60 \%$ peningkatan risiko meninggal akibat penyakit kardiovaskular saat 10 tahun kemudian dibandingkan dengan yang tidak terpapar kebisingan. ${ }^{9}$ Beberapa penelitian lain yang meneliti dampak kebisingan dengan gangguan kesehatan dilakukan oleh Jin et al. (2016), Siswati dan Adriyani (2017), dan Ismaila et al. (2014). Penelitian oleh Jin et al. (2016) membahas tentang perubahan hormon pada tikus yang terpapar kebisingan akut dan memperoleh hasil terdapat peningkatan yang signifikan terhadap hormon norepinefrin (hormon stres) pada hippocampus tikus. ${ }^{10}$ Sementara itu, penelitian Siswati dan Adriyani (2017) menyebutkan bahwa pada karyawan unit produksi PT. Industri Kemasan Semen Gresik (IKSG) dengan jumlah responden sebanyak 22 orang yang terpapar kebisingan rata-rata sebesar 90,8 dB(A) didapatkan hubungan yang signifikan antara kebisingan dengan kenaikan tekanan darah sistolik, diastolik, dan denyut nadi. ${ }^{11}$ Berbeda dengan sebelumnya, penelitian Ismaila et al. (2014) tentang pengaruh paparan kebisingan terhadap peningkatan tekanan darah pada pekerja pabrik karung dengan responden sebesar 62 pekerja laki-laki dan intensitas bising rata-rata sebesar 92,85 $\mathrm{dBA}$, menunjukkan hasil peningkatan tekanan darah sistolik yang signifikan. Sementara untuk tekanan diastolik, menunjukkan hasil yang tidak signifikan. ${ }^{1}$

Faktor individu yang mempengaruhi peningkatan tekanan darah dan denyut nadi dapat berupa usia, perilaku merokok, kondisi stres, dan kondisi fisik rendah $\mathrm{O}_{2}{ }^{5,12,13}$ Pertambahan usia menyebabkan adanya perubahan fisiologis dalam tubuh seperti penebalan dinding arteri akibat adanya penumpukan zat kolagen pada lapisan otot, sehingga pembuluh darah akan mengalami penyempitan, kaku, dan berkurang tingkat elastisitasnya (arteriosklerosis) yang dialami manusia saat berusia 40 tahun. ${ }^{14,15}$ Kebisingan akut dapat memicu kondisi stres yang akan mengaktivasi sistem saraf simpatis dengan cara memproduksi hormon epinefrin dan norepinefrin yang menyebabkan pembuluh darah menjadi vasokontriksi sehingga menaikkan cardiac output dan resistensi perifer. ${ }^{10,16}$ Ketika kondisi tubuh kekurangan $\mathrm{O}_{2}$ (hipoksia), $\mathrm{CO}_{2}$ (hipokapnia), dan kadar asam yang tinggi (asidosis) dalam darah, terutama kondisi saat seseorang terpapar asap rokok maupun sedang merokok menyebabkan kemoreseptor pada badan aorta dan karotis menjadi aktif, sehingga akan mengirimkan impuls eksitatorik ke pusat kardiovaskular dan berakibat meningkatnya tekanan darah dan denyut nadi. ${ }^{17,18}$

Faktor lingkungan yang sangat berpengaruh terhadap peningkatan tekanan darah dan denyut nadi adalah paparan kebisingan di tempat kerja. ${ }^{1,5,9}$ Saraf simpatis yang mendapat stimulasi akan mempengaruhi pembuluh darah arteriol dan vena sehingga menyebabkan vasokontriksi. Vasokontriksi yang terjadi pada arteriol akan menyebabkan peningkatan resistensi perifer total (total peripheral resistance) sehingga tekanan darah meningkat. Ketika vena juga mengalami vasokontriksi, maka akan terjadi peningkatan aliran balik vena, sehingga isi sekuncup (stroke volume) dan cardiac output meningkat. Dengan meningkatnya cardiac output, mengakibatkan tekanan darah meningkat. Jika hal ini terjadi dalam jangka waktu hingga lima tahun, maka dapat menyebabkan hipertensi dan memiliki $60 \%$ lebih tinggi risiko kematian akibat penyakit kardiovaskular dalam kurun 
waktu lebih dari 10 tahun, dibandingkan dengan pekerja yang tidak pernah terpapar kebisingan. ${ }^{9,14}$

Pemerintah berupaya untuk melindungi pekerja dari bahaya kebisingan di lingkungan industri dengan mengeluarkan Peraturan Menteri Tenaga Kerja dan Transmigrasi No. PER/13/MEN/X/2011 tentang Nilai Ambang Batas Faktor Fisika dan Faktor Kimia di Tempat Kerja. Dalam peraturan tersebut ditetapkan Nilai Ambang Batas (NAB) kebisingan sebesar 85 $\mathrm{dB}(\mathrm{A})$. Nilai tersebut merupakan nilai tertinggi yang masih dapat diterima oleh pekerja tanpa mengakibatkan penyakit atau gangguan kesehatan dalam pekerjaan untuk waktu yang tidak melebihi 8 jam sehari atau 40 jam seminggu. ${ }^{19}$

Humas Pemkab Jember (2014) menyebutkan bahwa sebesar 36,6\% Kabupaten Jember berada pada wilayah datar dengan kemiringan lahan $0-2 \%$ sehingga daerah ini baik untuk kawasan pemukiman dan kegiatan pertanian dengan lahan kawasan hijau yang terdiri atas hutan, sawah, tegal dan perkebunan. Salah satu tanaman perkebunan adalah pohon sengon. Jember dikenal sebagai penghasil komoditi kayu sengon yang cukup berkembang. Hal ini dapat dibuktikan dengan produksi kayu sengon yang mengalami surplus mencapai 90.026,25 $\mathrm{m}^{3}$ dan dikirim ke luar Kabupaten, diantaranya adalah Lumajang, Probolinggo, Banyuwangi, bahkan ke Jawa tengah. Pada tahun 2011 terdapat sekitar 90\% dari total area hutan rakyat seluas $28.168,81 \mathrm{Ha}$ adalah pohon sengon, sedangkan komoditas lainnya adalah pohon jati, mahoni, sonokeling dan mindi. ${ }^{20}$

Investasi pohon sengon yang sedemikian besar di Jember menimbulkan potensi yang besar untuk mengolahnya sehingga telah dibangun beberapa perusahaan jasa penggergajian yang memproduksi palet, balken, papan cor dan bahan peti kemasan yang berjumlah 24 perusahaan. ${ }^{20}$ Salah satu perusahaan yang dimaksud adalah PT. Muroco Jember. Pabrik kayu ini berdiri sejak 2008 dengan jumlah pekerja yang mencapai 300 orang. Proses dalam pabrik ini meliputi pengangkutan kayu, tahapan penggergajian gelondongan kayu menjadi balok kayu atau lembaranlembaran kayu, proses pengeleman yang menggunakan tekanan panas hingga proses finishing serta packing. Proses penggergajian kayu menimbulkan bunyi karena terdapat gesekan terus-menerus antara mesin gergaji dan gelondongan kayu. Selain itu, mesin pengeleman dengan tekanan panas juga menimbulkan bunyi akibat aktivitas yang ditimbulkan oleh mesin. Berdasarkan korespondensi yang dilakukan oleh peneliti dan Kepala Bagian Human Resources Development (HRD) PT. Muroco Jember, bahwa belum pernah dilakukan pengukuran intensitas kebisingan pada area produksi dan penelitian terkait oleh dampaknya kebisingan dengan kesehatan pekerja. Penelitian ini bertujuan untuk menganalisis pengaruh kebisingan akut terhadap tekanan darah dan denyut nadi pada pekerja pabrik kayu PT. Muroco Jember.

\section{MATERI DAN METODE}

Penelitian ini berjenis analitik observasional dengan desain penelitian cross sectional. Pengambilan data penelitian dilaksanakan pada tanggal $15-21$ Desember 2017 di pabrik kayu PT. Muroco Jember. Responden penelitian ini adalah keseluruhan pekerja shift pagi pada populasi terjangkau yang memenuhi kriteria inklusi dan eksklusi penelitian, sejumlah 24 responden dengan teknik total sampling. Kriteria inklusi meliputi pekerja berjenis kelamin laki-laki, berusia antara 18-40 tahun, memiliki masa kerja lebih dari 1 tahun, memiliki indeks massa tubuh antara 18-25 $\mathrm{kg} / \mathrm{m}^{2}$, bekerja pada shift pagi, dan menempati sektor kerja yang terlindungi dari sinar matahari, sedangkan kriteria ekslusi meliputi pekerja yang mengidap kelainan jantung, sedang menjalani pengobatan hipertensi, dan mengonsumsi alkohol dalam kurun 1 bulan terakhir. Seluruh responden penelitian telah mendapatkan penjelasan tentang rangkaian penelitian dan telah menandatangani informed consent. Analisis data dilakukan terhadap data yang diperoleh dari 24 responden yang mengikuti penelitian hingga selesai.

Pengukuran intensitas kebisingan menggunakan alat sound level meter pada 4 sektor kerja, yaitu sawmill A, sawmill B, produksi A, dan produksi B. Pengukuran dilakukan sebanyak 6 kali pada masing-masing sektor kerja dengan rentang waktu 30 detik. Dari hasil tersebut, dilakukan penghitungan rata-rata untuk mendapatkan nilai intensitas kebisingan pada masingmasing sektor kerja.

Pengumpulan data karakteristik pekerja menggunakan kuesioner. Pengukuran takanan darah dan nadi responden dilakukan sebelum dan setelah bekerja. Untuk pengukuran tekanan darah menggunakan sphygmomanometer air raksa, sedangkan pengukuran denyut nadi menggunakan teknik palpasi pada arteri brachialis. Analisis data menggunakan uji komparasi paired t-test pada level signifikansi 5\%. Penelitian ini telah mendapatkan ijin dari dari Komisi Etik Fakultas Kedokteran Universitas Jember melalui nomor surat 1228/H25.1.11/KE/2017 pada tanggal 13 Desember 2017.

\section{HASIL DAN PEMBAHASAN}

Penelitian ini merupakan jenis penelitian cross sectional yang bertujuan mengetahui hubungan antara intensitas kebisingan dengan tekanan darah dan denyut nadi pada pekerja Pabrik Kayu PT. Muroco Jember. Pada penelitian sebelumnya menyatakan bahwa kebisingan dapat meningkatkan tekanan darah dan denyut nadi pekerja, serta dapat meningkatkan resiko meninggal dunia akibat penyakit kardiovaskular pada beberapa tahun mendatang. ${ }^{1,9,11}$ Pengukuran tekanan darah dan denyut nadi sebelum dan sesudah bekerja selama 8 jam merujuk pada efek akut yang ditimbulkan dari kebisingan di sektor kerja dengan melihat perubahan yang terjadi. Hasil penelitian ini menunjukkan sebanyak $33,3 \%$ responden penelitian berusia $18-28$ tahun dan $66,7 \%$ responden penelitian berusia 29-40 tahun, dengan masa kerja $\leq 2$ tahun 
sebanyak $62,5 \%$ dan $>2$ tahun sebanyak $37,5 \%$. Hal ini dapat diartikan bahwa sebagian besar pekerja masih tergolong pekerja baru, karena mengingat pabrik kayu
PT. Muroco Jember didirikan sejak tahun 2008. Karakteristik responden dapat dilihat pada Tabel 1.

Tabel 1. Karakteristik responden berdasarkan usia, masa kerja, dan penggunaan APT

\begin{tabular}{lccccc}
\multicolumn{5}{c}{ di pabrik kayu PT. Muroco Jember } \\
\hline \multicolumn{1}{c}{ Karakteristik } & Min. & Max. & Rerata \pm SD & n (Orang) & $\%$ \\
\hline usia (th) & 22 & 40 & $30,9 \pm 5,8$ & & \\
$\quad 18-28$ & & & & 8 & 33,3 \\
$29-40$ & & & & 16 & 66,7 \\
masa kerja (th) & 1 & 9 & $2,7 \pm 2,2$ & & \\
$\quad \leq 2$ & & & & 15 & 62,5 \\
$\quad>2$ & & & & 9 & 37,5 \\
Penggunaan APT & & & & 22 & 91,7 \\
Tidak & & & 2 & 6,3 \\
Ya & & & & & \\
\hline
\end{tabular}

Kewajiban penggunaan alat pelindung telinga (APT) diberlakukan kepada semua sektor yang diteliti, dan didapatkan data bahwa sebanyak $91,7 \%$ responden tidak memakai APT. Menurut responden, hal tersebut lebih dikarenakan rasa yang tidak nyaman saat menggunakan APT dalam jangka waktu yang lama. Tanpa pemakaian APT saat bekerja, hal tersebut dapat meningkatkan risiko penyakit akibat kerja. Meskipun pihak perusahaan sudah menyediakan APT jenis ear plug, namun akan lebih baik jika menyediakan APT jenis ear muff. Penggunaan APT jenis ear muff dapat mengurangi kebisingan sebesar 40-50 dB(A), sedangkan APT jenis ear plug hanya bisa mengurangi kebisingan hingga $30 \mathrm{~dB}(\mathrm{~A})$.

Terdapat 4 sektor kerja yang diizinkan oleh pihak perusahaan untuk dilakukan penelitian, yaitu sawmill A, sawmill B, produksi A, dan produksi B. Pengukuran intensitas kebisingan di setiap sektor kerja dilakukan dengan menggunakan alat sound level meter sebanyak 6 kali dengan rentang waktu 30 detik. Dari hasil tersebut, dilakukan penghitungan rata-rata untuk mendapatkan nilai intensitas kebisingan pada masingmasing sektor kerja tersebut. Intensitas kebisingan terkecil berada pada sektor kerja pengangkutan dan intensitas kebisingan terbesar pada sektor kerja sawmill B. Berdasarkan data penelitian, pada sektor sawmill A dan sawmill B memiliki intensitas kebisingan di atas $90 \mathrm{~dB}(\mathrm{~A})$. Peraturan Menteri Tenaga Kerja dan Transmigrasi No. PER/13/MEN/X/2011 tentang Nilai Ambang Batas Faktor Fisika dan Faktor Kimia di Tempat Kerja menyatakan bahwa lama waktu kerja yang diperkenankan untuk tenaga kerja yang terpapar lingkungan bising sebesar $91 \mathrm{~dB}(\mathrm{~A})$ adalah selama 2 jam/hari. Faktanya, durasi kerja responden penelitian di sawmill A dan sawmill B dalam satu shift adalah sekitar 8 jam. Oleh karena itu responden penelitian yang berada di sawmill A dan sawmill B dengan intensitas kebisingan di atas NAB, memiliki risiko yang lebih tinggi untuk mengalami kejadian penyakit akibat kerja. Distribusi reponden pada sektor kerja dan hasil pengukuran intensitas kebisingan dapat dilihat pada Tabel 2.

Tabel 2. Distribusi responden pada sektor kerja dan hasil pengukuran intensitas kebisingan

\begin{tabular}{ccccc}
\hline No. & Sektor Kerja & $\begin{array}{c}\text { Jumlah } \\
(\text { Orang) }\end{array}$ & $\begin{array}{c}\text { Persentase } \\
(\%)\end{array}$ & $\begin{array}{c}\text { Intensitas Kebisingan } \\
(\mathrm{dBA})\end{array}$ \\
\hline 1 & sawmill A & 7 & 29,2 & 91,5 \\
2 & sawmill B & 10 & 41,7 & 98,1 \\
3 & produksi A & 5 & 20,8 & 82,9 \\
4 & produksi B & 2 & 8,3 & 84,9 \\
\hline
\end{tabular}

Pengukuran tekanan darah sistolik dan diastolik responden dilakukan sebelum dan setelah bekerja selama 8 jam. Pengukuran tekanan darah sistolik sebelum kerja menunjukkan rata - rata sebesar 118,9 \pm 8,3 $\mathrm{mmHg}$, sedangkan pengukuran tekanan darah sistolik setelah kerja menunjukkan rata - rata sebesar 125,2 \pm 9,7 mmHg. Data penelitian menunjukkan terjadi peningkatan rata-rata tekanan darah sistolik responden penelitian.

Pengukuran tekanan darah diastolik sebelum kerja menunjukkan rata-rata sebesar 76,7 $\pm 8,1 \mathrm{mmHg}$, sedangkan pengukuran tekanan darah diastolik setelah kerja menunjukkan rata-rata sebesar 78,6 \pm 6,6 mmHg. Data penelitian menunjukkan terjadi peningkatan ratarata tekanan darah diastolik responden penelitian.

Pengukuran denyut nadi sebelum kerja menunjukkan rata - rata sebesar 78,5 $\pm 8,7 \mathrm{kali} /$ menit, sedangkan pengukuran denyut nadi setelah kerja menunjukkan rata - rata sebesar 82,2 $\pm 6,5 \mathrm{kali} /$ menit. Data penelitian menunjukkan terjadi peningkatan ratarata denyut nadi responden penelitian. Tabulasi tekanan darah sistolik, diastolik, dan denyut nadi responden sebelum dan setelah bekerja dapat dilihat pada Tabel 3 . 
Tabel 3. Tabulasi tekanan darah sistolik, diastolik, dan denyut nadi responden sebelum dan setelah bekerja

\begin{tabular}{|c|c|c|c|c|c|c|}
\hline Variabel & Pengukuran & Min. & Max. & Rerata \pm SD & n (orang) & $\%$ \\
\hline tekanan darah sistolik & pre & 104 & 130 & $118,9 \pm 8,3$ & & \\
\hline \multirow[t]{9}{*}{$(\mathrm{mmHg})$} & $\leq 110$ & & & & 7 & 29,2 \\
\hline & $111-120$ & & & & 7 & 29,2 \\
\hline & $121-130$ & & & & 10 & 41,6 \\
\hline & $>130$ & & & & 0 & 0 \\
\hline & post & 102 & 140 & $125,2 \pm 9,7$ & & \\
\hline & $\leq 110$ & & & & 1 & 4,2 \\
\hline & $111-120$ & & & & 8 & 33,3 \\
\hline & $121-130$ & & & & 10 & 41,7 \\
\hline & $>130$ & & & & 5 & 20,8 \\
\hline tekanan darah diastolik & pre & 60 & 94 & $76,7 \pm 8,1$ & & \\
\hline \multirow[t]{9}{*}{$(\mathrm{mmHg})$} & $\leq 70$ & & & & 8 & 33,3 \\
\hline & $71-80$ & & & & 12 & 50,0 \\
\hline & $81-90$ & & & & 3 & 12,5 \\
\hline & $>90$ & & & & 1 & 4,2 \\
\hline & post & 66 & 90 & $78,6 \pm 6,6$ & & \\
\hline & $\leq 70$ & & & & 6 & 25,0 \\
\hline & $71-80$ & & & & 13 & 54,2 \\
\hline & $81-90$ & & & & 5 & 20,8 \\
\hline & $>90$ & & & & 0 & 0 \\
\hline denyut nadi & pre & 62 & 92 & $78,5 \pm 8,7$ & & \\
\hline \multirow[t]{9}{*}{ (kali/menit) } & $\leq 70$ & & & & 6 & 25,0 \\
\hline & $71-80$ & & & & 9 & 37,5 \\
\hline & $81-90$ & & & & 7 & 29,2 \\
\hline & $>90$ & & & & 2 & 8,3 \\
\hline & post & 69 & 94 & $82,2 \pm 6,5$ & & \\
\hline & $\leq 70$ & & & & 1 & 4,2 \\
\hline & $71-80$ & & & & 11 & 45,8 \\
\hline & $81-90$ & & & & 10 & 41,7 \\
\hline & $>90$ & & & & 2 & 8,3 \\
\hline
\end{tabular}

Hasil uji normalitas data menyatakan bahwa data terdistribusi tidak normal $(\mathrm{p}<0,05)$, sehingga dilakukan transformasi data. Hasil dari transformasi data dilakukan uji normalitas lagi dan dinyatakan data terdistribusi normal $(\mathrm{p}>0,05)$. Uji komparasi yang digunakan adalah uji paired t-test untuk ketiga kelompok data. Hasil uji komparasi paired t-test kebisingan akut terhadap tekanan darah sistolik, diastolik, denyut nadi sebelum dan setelah bekerja pada responden Pabrik Kayu PT. Muroco Jember menyatakan bahwa terdapat peningkatan yang signifikan terhadap tekanan darah sistolik, diastolik, denyut nadi antara sebelum dan sesudah bekerja dalam paparan kebisingan akut $(p<0,05)$. Hasil uji komparasi paired t-test kebisingan terhadap tekanan darah sistolik, diastolik dan denyut nadi dapat dilihat pada Tabel 4.

Tabel 4. Hasil uji komparasi paired t-test kebisingan dengan tekanan darah sistolik, diastolik, dan denyut nadi

\begin{tabular}{lccc}
\hline & $\mathrm{N}$ & Rerata \pm S.D & $p$ \\
\hline sistolik sebelum kerja & 24 & $118,9 \pm 8,3$ & $<0,001$ \\
sistolik setelah kerja & 24 & $125,2 \pm 9,7$ & \\
\hline diastolik sebelum kerja & 24 & $76,7 \pm 8,1$ & 0,049 \\
diastolik setelah kerja & 24 & $78,6 \pm 8,7$ & \\
\hline denyut nadi sebelum kerja & 24 & $78,5 \pm 8,7$ & 0,020 \\
denyut nadi setelah kerja & 24 & $82,2 \pm 6,5$ & \\
\hline
\end{tabular}

Hasil uji komparasi paired t-test menyatakan bahwa terdapat peningkatan yang signifikan terhadap tekanan darah sistolik, diastolik, denyut nadi antara sebelum dan setelah bekerja dalam paparan kebisingan akut. Hasil ini sejalan dengan penelitian yang menyatakan bahwa terdapat peningkatan yang signifikan terhadap tekanan darah dan denyut nadi antara sebelum dan setelah bekerja pada paparan kebisingan akut. $1,5,11$

Hasil yang signifikan ini sesuai dengan dasar teori yang telah dijelaskan oleh beberapa literatur dan penelitian. Kebisingan akut dianggap sebagai suatu stressor oleh tubuh yang jalur masuknya sama dengan jalur masuk bunyi menuju sistem pendengaran. Paparan kebisingan akut yang tinggi dapat 
mengaktifkan sistem saraf simpatis dan menginduksi perubahan hormonal dalam tubuh yang diperankan oleh hypothalamic-pituitary-adrenal (HPA) axis. ${ }^{10}$ Sistem saraf simpatis yang diaktifkan oleh hipotalamus menyebabkan produksi hormon epinefrin dan norepinefrin oleh medulla adrenal menjadi tinggi. Hal ini didukung oleh penelitian Jin et al. (2016) yang menyatakan bahwa terdapat peningkatan yang signifikan terhadap kadar hormon norepinefrin pada tikus yang terpapar kebisingan akut $(p=0,019)$. Kadar hormon yang tinggi ini mengakibatkan pengaruh ke beberapa organ, diantaranya yaitu jantung dan pembuluh darah. ${ }^{21}$ Rangsangan simpatis akan meningkatkan seluruh aktivitas jantung seperti meningkatnya frekuensi dan kontraksi jantung yang berimplikasi pada peningkatan tekanan darah dan denyut nadi manusia. Sebagian besar pembuluh darah sistemik akan mengalami vasokontriksi bila ada perangsangan simpatis. Bila terjadi vasokontriksi, resistensi pembuluh darah menjadi besar sehingga mampu untuk meningkatkan tekanan darah. ${ }^{17}$

Penelitian ini memiliki kelebihan pada instrumen pengukuran tekanan darah. Peneliti memakai sphygmomanometer air raksa yang telah dikalibrasi dan dinilai sebagai gold standard pengukuran tekanan darah, sehingga diharapkan mendapatkan nilai yang akurat sesuai dengan kondisi responden. Penggunaan teknik total sampling dengan memilih responden berdasar kriteria inklusi dan eksklusi diharapkan mampu menghomogenkan responden penelitian sehingga didapatkan hasil penelitian yang lebih valid.

Peneliti menyadari beberapa keterbatasan dalam penelitian ini. Pertama, sampel penelitian yang digunakan masih dikatakan sedikit dibandingkan penelitian-penelitian sebelumnya. Hal ini dikarenakan kebijakan pabrik yang hanya mengijinkan 4 sektor saja untuk dilakukan penelitian terkait waktu pengukuran dan jumlah pengukuran tekanan darah. Kedua, pengukuran tekanan darah hanya dilakukan satu kali dalam setiap pengukuran. Hal ini dapat menyebabkan hasil pengukuran menjadi kurang akurat meskipun telah memakai alat gold standard untuk tekanan darah. Penelitian selanjutnya diharapkan melakukan pengukuran tekanan darah sebanyak 2-3 kali untuk memastikan keakuratan nilai pengukuran. Ketiga, beberapa faktor internal dan eksternal dapat mempengaruhi peningkatan tekanan darah dan denyut nadi yang tidak dikontrol peneliti, seperti penyakit pendengaran responden, tingkat kelelahan kerja, dan tingkat stres pekerja. Penelitian selanjutnya diharapkan mengontrol faktor lain yang diduga berpengaruh dalam peningkatan tekanan darah dan denyut nadi..

\section{SIMPULAN}

Penelitian ini menyimpulkan: 1) terdapat peningkatan yang signifikan terhadap tekanan darah sistolik, diastolik, denyut nadi antara sebelum dan setelah bekerja dalam paparan kebisingan akut pada responden Pabrik Kayu PT. Muroco Jember; 2) intensitas kebisingan pada sawmill A, sawmill B, produksi $A$, dan produksi $B$ berturut-turut adalah 91,5 $\mathrm{dB}(\mathrm{A}), 98,1 \mathrm{~dB}(\mathrm{~A}), 82,9 \mathrm{~dB}(\mathrm{~A})$, dan 84,9 dB(A); 3) sebagian besar responden berusia antara 29-40 tahun $(66,7 \%)$, memiliki masa kerja $<2$ tahun sebanyak $62,5 \%$, dan tidak menggunakan APT sebanyak 91,7\%.

\section{DAFTAR PUSTAKA}

1. Ismaila SO, Odusote A. Noise exposure as a factor in the increase of blood pressure of workers in a sack manufacturing industry. Beni-Suef University Journal of Basic and Applied Sciences 2014, 3(2): 116-121.

2. Laad M. The study of the effect of sounds of constant frequency and varying intensity levels on systolic blood pressure, diastolic blood pressure and heart rate of healthy individuals. International Journal of Engineering 2011, 9(3): 107-109.

3. Bridger RS. Introduction to Ergonomics. New York: McGraw-Hill Book Corporation; 1995.

4. Keputusan Menteri Negara Lingkungan Hidup Nomor KEP-48/MENLH/11/1996. Baku Tingkat Kebisingan. Jakarta; 1996.

5. Assunta C, Ilaria S, Simone DS, Gianfranco T, Teodorico C, Carmina S, Anastasia S, Roberto G, Francesco T, Valeria RM. Noise and cardiovascular effects in workers of the sanitary fixtures industry. International Journal of Hygiene and Environmental Health 2014, 218 (1): 163-168.

6. Leather P, Beale D, Sullivan L. Noise, psychosocial stress and their interaction in the workplace. Journal of Environmental Psychology 2003, 23(2): 213-222.

7. Stokholm ZA, Hansen AM, Grynderup MB, Bonde JP, Christensen KL, Frederiksen TW, Lund SP, Vestergard JM, Kolstad HA. Recent and long-term occupational noise exposure and salivary cortisol level. Psychoneuroendocrinology 2013, 39(1): 2132.

8. Attarchi M, Dehghan F, Safakhah F, Nojomi M, Moham S. Effect of exposure to occupational noise and shift working on blood pressure in rubber manufacturing company workers. Ind Health 2012, 50(3): 205-213.

9. Gopinath B, Thiagalingam A, Teber E, Mitchell P. Exposure to workplace noise and the risk of cardiovascular disease events and mortality among older adults. Preventive Medicine 2011, 53(6): 390394.

10. Jin SG, Kim MJ, Park SY, Park SN. Stress hormonal changes in the brain and plasma after acute noise exposure in mice. Auris Nasus Larinx 2016, 44(3): 272-276.

11. Siswati, Adriyani R. Hubungan pajanan kebisingan dengan tekanan darah dan denyut nadi pada pekerja industri kemasan semen. Jurnal Kesehatan Lingkungan Indonesia 2017, 16 (1): 29-36.

12. Chang TY, Lai YA, Hsieh HH, Lai JS, Liu CS. Effects of environmental noise exposure on ambulatory blood pressure in young adults. Environmental Research 2009, 109(7): 900-905. 
13. Zeeb H, Hegewald J, Schubert M, Wagner M, Droge P, Swart E, Seidler A. Traffic noise and hypertension - results from a large case-control study. Environment Research 2017, 157(1): 110117.

14. Lusk SL, Arbor A, Hagerty BM, Ziemba RA. Acute effects of noise on blood pressure and heart rate. Environmental Health 2004, 59(8): 392-399.

15. Lionakis N, Mendrinos, Dimitrios, Sanidas, Elias, Favatas. Hypertension in the elderly. World Journal of Cardiology 2012, 4(5): 135-147.

16. Hastuti E. Faktor-Faktor Risiko Kenaikan Tekanan Darah pada Pekerja yang Terpajan Kebisingan di Bandara Ahmad Yani Semarang. Tesis. Semarang; 2005.

17. Aaronson PI, Ward J. The Cardiovascular System at a Glance. Third Edition. England: Blackwell Publishing Ltd. Terjemahan oleh J. Surapsari. 2008. At a Glance Sistem Kardiovaskular. Edisi Ketiga. Jakarta; 2007.
18. Walker ED, Brammer A, Cherniack MG, Laden F, Cavallari JM. Cardiovascular and stress responses to short-term noise exposures - A panel study in healthy males. Environmental Research 2016, 150(1): 391-397.

19. Peraturan Menteri Tenaga Kerja dan Transmigrasi Nomor PER.13/MEN/X/2011 Tahun 2011. Nilai Ambang Batas Faktor Fisika dan Faktor Kimia di Tempat Kerja. 28 Oktober 2011. Jakarta; 2011.

20. Humas Pemkab Jember. 2014. Potensi Perkebunan dan Kehutanan. https://jemberkab.go.id/potensiperkebunan-dan-kehutanan/. [Diakses pada 26 September 2017].

21. Guyton AC, Hall JE. Textbook of Medical Physiology. Eleventh Edition. Singapore: Elsevier's Health Science Rights Department. Terjemahan oleh Irawati et al. Buku Ajar Fisiologi Kedokteran. Edisi Kesebelas. Jakarta; 2006. 